УДК 341.13

DOI https://doi.org/10.32849/2663-5313/2020.5.57

Микола Вечеря, аспірант кафедри права

ПВНЗ «Европейський університет»

\title{
ЗАРУБІЖНИЙ ДОСВІД ЗАБЕЗПЕЧЕННЯ БЕЗПЕКИ СВІДКА В КРИМІНАЛЬНОМУ ПРОЦЕСІ
}

У статі розглянуто проблемні аспекти захисту безпеки свідка як особи, що бере участь у кримінальному судочинстві. Висвітлено стан нормативного забезпечення безпеки свідка з використанням порівняльно-правового аналізу начіонального законодавства із законодавством окремих зарубіжних країн. З'ясовано перспективні можливості імплементації деяких аспектів зарубіжного законодавства до законодавчих актів начіональної правової системи. Визначено, що в законодавстві Республіки Австрія, а саме у Федеральному законі № 526, чітко визначене коло свідків, які можуть бути включені до програми захисту свідків. Згідно з иим законом свідками є особи, яким загрожує небезпека у зв'язку з тим, що вони володіють значною інформачією щодо справ про злочини, які пов'язані з організованою злочинністю, про злочини проти державного устрою, про злочини у сфері незаконного обігу наркотиків та деякі інші тяжкі злочини. Заходи безпеки Австрії подібні до заходів безпеки європейських держав: перемішення свідка на безпечну територію, переселення в інше місие проживання (інше місто, або навіть інша держава); створення нової «історії» життя особи (легенди), оформлення нових документів; особиста охорона; зміна документів особи; встановлення зв'язку нових документів з наявними базами даних; відстеження почтових та електронних повідомлень на основі паролів та логінів, які надала підзахисна особа; соиіальна адаптачія на новому місиі проживання; психологічна допомога потерпілому (свідку) тощо. З'ясовано, що законодавство Франиії, маючи на меті максимально можливий захист свідків, допускає навіть повну анонімність свідчень особи. Це є досить дієвим стимулом до дачі особою таких свідчень та надає можливість правоохороннім органам значно спростити проиедуру захисту свідка. Зроблено висновок, що поняття захисту свідків та потерпілих повинно включати в себе забезпечення всіх трьох складників. Проте поняття забезпечення безпеки у законі та теорії кримінального процесу не тотожні, при иьому в теорії наразі немає загальноприйнятого визначення терміна «забезпечення безпеки».

Ключові слова: порівняльно-правове законодавство, кримінальне провадження, захист учасників кримінального судочинства, програма захисту свідка.

Постановка проблеми. Досить актуальним нині є питання захисту учасників кримінального судочинства від незаконного фізичного або психічного впливу. Одним з основних напрямів для виявлення, попередження, розкриття, розслідування та запобігання злочинності є належним чином проведене розслідування кримінального правопорушення. Беззаперечно, в процесі розслідування злочину правоохоронними органами важко переоцінити важливість показів свідків злочину.

Однак досить велика кількість свідків замовчують факти, що стосуються вчинення злочину, та не звертаються до відповідних правоохоронних органів або суду. Це призводить до зростання індексу латентності злочинів, безкарності злочинців, порушення нормального ритму життедіяльності громадянського суспільства.

У більшості зарубіжних країн до осіб, що $€$ носіями певної юридично значущої інформації, застосовується досить велика кількість різноманітних, гарантованих державою заходів із забезпечення їх перебування у якості свідка та подальшого безпечного існування. Здійснення такого захисту стало досить значною потребою і для українського суспільства.

Програми, що спрямовані на захист свідків у розвинених державах світу, надають не тільки фізичний захист, але й моральну та матеріальну допомогу потерпілим, свідкам й іншим учасникам кримінального судочинства. Такого роду програми ефективно працюють у Сполучених Штатах Америки, Німеччині, Республіці Австрія, Франції та багатьох інших державах світу.

У нашій державі щодо даної проблематики діє Закон України від 23.12.1993 р. № 3782-XII «Про забезпечення безпеки осіб, що беруть участь у кримінальному судочинстві». Спеціальної ж програми чи програм, що забезпечує захист осіб, що беруть участь у кримінальному процесі, немає.

Лише в розпорядженні КМУ від 15 листопада 2017 р. № 1023-р «Про схвалення 
Стратегії розвитку органів системи Міністерства внутрішніх справ на період до 2020 року» [1] передбачено пункт щодо розроблення і впровадження разом 3 іншими державними органами оптимальної системи захисту свідків в Україні. Саме відсутністю всеохоплюючої належної національної нормативної бази із захисту прав свідка і вмотивовується актуальність даного дослідження.

Стан дослідження. Дослідженням вищевказаної проблеми в різний час займалися такі вчені, як: М.Ю. Азаров, А.Н. Ахпанов, В.П. Бахін, В.І. Бояров, Л.В. Брусніцин, В.К. Весельський, В.В. Войников, В.І. Галаган, В.В. Гевко, О.О. Гриньків, Ю.В. Гуцуляк, О.Ю. Єпіхін, Є.В. Жаріков, О.О. Зайцев, В.С. Зеленецький Н.С. Карпов, Є.Є. Кондратьєв, В.С. Кузьмічов, М.В. Куркін Є.Д. Лук'янчиков, А.О. Ляш, В.Т. Маляренко, М.В. Новикова, Т.І. Панасюк, Н.В. Пелипенко, М.А. Погорецький, К.О. Ромодановський, С.М. Стахівський, А.А. Тимошенко, P.P. Трагнюк, В.M. Тертишник, О.В. Усенко, Л.М. Шестопалова, С.П. Щерба, А.А. Юнусов, С.О. Янін та ін. Проте, незважаючи на масивний перелік дослідників, є потреба в подальшому опрацюванні зарубіжного досвіду з виробленням рекомендацій з удосконалення національного законодавства.

Метою даної роботи є аналіз законодавчої бази деяких зарубіжних країн 3 приводу належного забезпечення захисту прав свідка у кримінальному провадженні.

Виклад основного матеріалу. Ефективність кримінального судочинства багато в чому залежить від повноти та всебічного розслідування обставин справи, встановлення фактів та відомостей, що дозволяють правильно оцінити докази та прийняти рішення у конкретному провадженні. Найбільш важливим та «достовірним» джерелом таких фактів та відомостей завжди вважали показання свідків, потерпілих та інших учасників кримінального провадження, хоча й за такими доказами немає наперед встановленої сили. Правдиві показання свідків дозволяють перевірити отримані в ході досудового розслідування відомості, встановити належність доказів, виявити нові. Таким чином, забезпечення участі свідків та інших осіб у кримінальному судочинстві є одним із головних завдань органів досудового розслідування та суду. На жаль, на практиці трапляються ситуації, коли потерпілі чи свідки відмовляються давати показання чи ухиляються від вчинення процесуальних дій, змінюють свої попередні свідчення (що $€$ вирішальним у дотриманні принципу безпосередньості дослідження доказів судом), надають неповні чи не досить чіткі показання 3 огляду на реальну чи потенційну загрозу застосування до них, їхніх родичів та членів сімей насильства, залякування, психічного примусу чи інших форм протиправного впливу [2].

Основним аргументом для свідка щодо надання правдивої та повної інформації 3 приводу вчиненого кримінального правопорушення, очевидцем якого він виявився, окрім бажання виконати свій громадський обов'язок, звісно, буде убезпечення його та його близьких від протиправного впливу з боку осіб, що вчинили даний злочин, або ж їх співучасників. Розглянемо на прикладі деяких зарубіжних країн можливості законодавчого та фінансово-організаційного аспекту захисту свідків.

Історично склалося, що найбільший досвід у встановлені та розвитку інституту захисту свідків серед зарубіжних країн мають США, де нині функціонує ефективна й надійна система підтримки жертв злочинів та громадян, які добровільно співпрацюють із правоохоронними органами та ризикують зазнати посягань злочинців [3].

На основі Програми захисту свідків, що функціонує в Сполучених Штатах були розроблені подібні програми в Словаччині, Австралії, Канаді, Південній Африці тощо. У рік прийняття Програми за її допомогою були захищені 92 свідки. У період з 1975 по 1977 рік в середньому 450 свідків щорічно залучалися в Програму, у першій половині 90-х років - близько 200 свідків на рік. До 1996 року кількість захищених становила близько 15000 осіб. Однією з основних умов є те, що жоден свідок не може бути прийнятий в Програму, якщо він не є «дуже важливим свідком по справі, яка стосується значного злочину, вчиненого організованою злочинною групою, чи іншого тяжкого злочину, і якщо тільки цей свідок підлягає небезпеці в результаті дачі показань». На додаток до цього критерію рекомендується, щоб щорічно в Програму приймалось не більше 360 свідків, оскільки лише такій кількості свідків може бути забезпечений захист [4].

3 моменту реалізації програми захисту свідків «WITSEC» в 1971 році іï можливостями скористалися 18400 осіб, з них 8500 свідків і 9900 членів їхніх сімей. У середньому через програму, таким чином, проходили 438 осіб за рік [5].

Окрім ефективних правових і практичних заходів забезпечення безпеки свідків, які застосовують у США, важливу роль відіграє створення ефективного механізму фінансування цих заходів та посилення кримінальної 
відповідальності за посягання на життя, здоров'я чи майно учасників кримінального процесу [6].

Уряд Сполучених Штатів Америки щороку виділяє на програму захисту близько 60-100 млн. доларів, а на кожну особу, щодо якої застосовують заходи забезпечення безпеки, - 40 тис. доларів. За період 1970-2005 pр. у США до програми захисту жертв злочинів включено понад 7500 свідків та 9600 членів їхніх сімей [7].

У США свідок, життя і здоров'я якого піддається небезпеці, до початку судового розгляду, а також на період його проведення можуть бути поміщені в спеціально обладнане приміщення, на час розслідування їм можуть бути наданні кодові імена. Свідкам в особливо серйозних кримінальних справах після свідчень у суді отримують документи на нове ім'я, їм присвоюються нові номера в системі соціального забезпечення, відшкодовуються витрати на переїзд на нове місце проживання, їм допомагають знайти роботу, для них розробляється нова біографія тощо. Крім того, в США діє федеральне законодавство, спрямоване проти спроб «за допомогою хабарів, неправдивих повідомлень, залякування або сили чи за допомогою погроз створювати перешкоди, затримати або перешкодити іншій особі повідомити слідчому інформацію, яка стосується будь-якого порушення кримінального закону США». Закон передбачає також покарання за завдання особистої або майнової шкоди будь-якій особі, яка надала інформацію слідчому [8].

Зважаючи на вищевикладене, можливо зробити висновок про те, що Програма захисту свідків США є досконалим інструментом із недопущення різного роду впливу на особу, що дає свідчення у кримінальному проваджені в якості свідка, а також врегульовує питання відшкодування шкоди особам, що їі зазнали в результаті надання показів, які викривають злочин.

Шодо законодавства Федеративної Республіки Німеччина (далі - ФРН), то 18 грудня 1986 року був прийнятий Закон «Про захист потерпілих», яким у кримінальне законодавство цієї країни було введене поняття «відшкодування збитків» i «примирення потерпілих» у перелік обставин, що пом'якшують кримінальну відповідальність.

Законом же від 9 липня 1989 року була посилена відповідальність за викрадення людини з метою вимагання (§ 239a) і захоплення заручників (§ 239в). Ці склади злочинів можуть бути розглянуті як кримінальноправові заходи системи безпеки учасників кримінального процесу [9].
У ФРН діє федеральна програма захисту свідків, а також приймаються регіональні (місцеві) програми. У цій країні застосовуються дві системи забезпечення безпеки свідка: довготривалий захист, який забезпечується всіма доступними поліцейськими методами (охорона за місцем його проживання, роботи, в громадському місці та особливо в залі суду), і друга система заходів забезпечення безпеки, яка повністю ізолює свідка від зовнішнього світу та спрямована на сприяння підзахисній особі у виборі нового місця проживання, роботи, в занятті власним бізнесом, а також у наданні необхідної допомоги матеріального плану [10].

Міністерство внутрішніх справ ФРН щорічно витрачає на програми захисту понад 50 млн. євро, а за необхідності має можливість виділити вдвічі більше [11].

КК ФРН у розділі ХХХ «Карані діяння на службі» 353d «Незаконне розголошення відомостей про судовий розгляд» вказано: «1. Порушуючи заборони закону, публічно повідомляе про судовий розгляд, проведення якого є закритим, або про зміст службового документа, що стосується справи», «2. Порушуючи заборони розголошення відомостей, встановлених судом на основі Закону, неправомірно розголошує відомості, які стали йому відомі в ході закритого судового розгляду, або про зміст документа, що стосується справи», «3. Публічно оголошує повний текст або основні частини обвинувального вироку або інші службові документи кримінального процесу, провадження про відшкодування збитків або дисциплінарного провадження до оголошення цих документів в публічному розгляді або до закінчення процесу» [12].

У кримінально-процесуальному законі ФРН закріплено, що захиснику може бути відмовлено в розгляді та ознайомленні 3 матеріалами справи, які містять відомості про особу, яку взято під захист (ст. 147 КПК ФРН). У ст. 247 КПК ФРН дозволено на час допиту особи, яка перебуває під захистом, видалення із залу судового засідання підсудного [13].

Відповідно до § 54 КПК ФРН офіційні співробітники Відомства з охорони Конституції або поліції, будучи державними службовцями спеціальних служб, можуть давати свідчення про обставини, відомості про які становлять службову таємницю, тільки з дозволу вищого органу (за винятком відомостей по агентурній роботі). Такий дозвіл дає співробітнику право давати свідчення від свого імені на основі свідчень, отриманих від агентурного робітника, без розголошення відомостей про нього. Крім цього, у ФРН 
практикується також допит самого секретного агента (інформатора). При цьому вони виступають у судовому засідання під псевдонімом, зберігаючи свою анонімність [12].

Розглянувши законодавчі акти ФРН 3 питання захисту свідків, можна зробити висновок, що ці законодавчі акти захищають не тільки свідка, але й агентів, що надають свідчення по матеріалах кримінальних проваджень. Це досить значна можливість у механізмі реалізації правосуддя та досягнення мети судового розгляду кримінальної справи - справедливого покарання злочинців.

Щодо законодавства Республіки Австрія, то у Федеральному законі № 526 цієї країни (згідно з яким були внесені зміни до КПК Австрії) чітко визначене коло свідків, які можуть бути включені до програми захисту свідків. Згідно з цим законом свідками є особи, яким загрожує небезпека у зв'язку з тим, що вони володіють значною інформацією щодо справ про злочини, які пов’язані з організованою злочинністю, про злочини проти державного устрою, про злочини у сфері незаконного обігу наркотиків та деякі інші тяжкі злочини. Заходи безпеки Австрії подібні до заходів безпеки європейських держав: переміщення свідка на безпечну територію, переселення в інше місце проживання (інше місто, або навіть інша держава); створення нової «історії» життя особи (легенди), оформлення нових документів; особиста охорона; зміна документів особи; встановлення зв'язку нових документів з наявними базами даних; відстеження почтових та електронних повідомлень на основі паролів та логінів, які надала підзахисна особа; соціальна адаптація на новому місці проживанні; психологічна допомога потерпілому (свідку) тощо [14].

Щодо законодавства Франції, то КК цієї країни (ст. 105, ст. 107, ст. 286) передбачено можливість звільнення від кримінальної відповідальності «учасника кримінального співтовариства, який заявив про його існування до порушення всякого кримінального переслідування і який сприяв затриманню співучасників (спільників). У ст. 62-1 КПК цієї країни, яка введена в дію на основі Закону від 21 січня 1995 року, допускається можливість анонімних свідчень (без вказування відомостей про місце проживання свідка, якщо він про це клопоче). Під час допиту в поліції дані про особу перевіряються, встановлюються, хоча в протоколі вказується тільки адреса комісаріату, де відбувається допит. Така адреса зберігається в наступних стадіях кримінального процесу. У кожному поліцейському відділку ведеться спеціальний банк даних, куди заносяться дані про реальне місце проживання свідка, який хочу зберегти це в таємниці. Така форма письмової фіксації цінної доказової інформації розцінюється як один із важливих способів забезпечення безпеки учасників процесу [15].

Тож можливо зробити висновок, що законодавство Франції, маючи на меті максимально можливий захист свідків, допускає навіть повну анонімність свідчень особи. Це є досить дієвим стимулом до дачі особою таких свідчень та надає можливість правоохороннім органам значно спростити процедуру захисту свідка.

Щодо стану речей з питання захисту свідків на території нашої держави можливо зазначити, що опитування прокурорів та слідчих дало такі результати: у 40 \% проваджень по злочинах проти життя і здоров'я особи мав місце протиправний вплив на свідків. За формами впливу перше місце посідає насильство - 43 \% випадків, на другому місці підкуп - 23 \%. У результаті таких дій близько третини осіб, що брали участь у кримінальному судочинстві, змінювали свідчення, ще третина - ухилялися від кримінального провадження [16].

Потрібно зауважити, що така ситуація викликає недовіру осіб до органів правопорядку та правосуддя. Неможливість захистити своїх громадян призводить до того, що більшість осіб бояться заявляти про факти та відомості, що можуть бути використані для цілей кримінального провадження. Особливо гостро ця проблема відчувається на фоні вчинення тяжких та особливо тяжких злочинів (резонансних та корупційних злочинів, військових злочинів), коли залякування свідків та потерпілих пов'язано з необмеженими можливостями організованої злочинності в Україні в тому числі.

В.Я. Шапакідзе виділяє процесуальну безпеку свідків як загальне поняття, складниками якої є фізична, психологічна та матеріальна безпека. Фізична безпека - це стан захищеності особи від будь-якого неправомірного посягання на її життя, здоров'я, тілесну недоторканність, свободу пересування та вибір місця перебування або проживання. Психологічна безпека - це стан захищеності особи від будь-якого вторгнення в іï̈ психічну діяльність у зв'язку з участю у кримінальному процесі, що штучно створює критичну життєву ситуацію у вигляді стресів, конфліктів, кризи і (або) спричинює супутню шкоду її здоров'ю. Матеріальна безпека - це стан захищеності особи від будьякого неправомірного посягання на її майно, наявні або потенційні доходи та матеріальні гарантії повноцінного учасника кримінального судочинства [17]. 
Таким чином, поняття захисту свідків та потерпілих повинно включати в себе забезпечення всіх трьох складників. Проте поняття забезпечення безпеки у законі та теорії кримінального процесу не тотожні, при цьому в теорії наразі немає загальноприйнятого визначення «забезпечення безпеки».

А.А. Юнусов вважає, що забезпечення безпеки учасників кримінального процесу та інших осіб - це діяльність компетентних органів, що спрямована на створення умов, за яких життю та здоров'ю цих осіб не загрожує небезпека, або на усунення небезпеки. Дане визначення не розкриває всіх суттєвих ознак забезпечення безпеки свідків та потерпілих, є доволі загальним.

B.M. Тертишник використовує таке визначення: забезпечення безпеки учасників кримінального процесу - це здійснення правових, організаційно-технічних та інших заходів, спрямованих на захист життя, здоров'я, житла, майна, честі та гідності цих осіб від протиправних посягань з метою створення необхідних умов для належного здійснення правосуддя [18]. Це поняття є більш вдалим, оскільки вказує на характер заходів що застосовуються, їх завдання, та, головне, мету - належне здійснення правосуддя. Законодавство України також оперує поняттям «забезпечення безпеки».

У ст. 1 Закону України «Про забезпечення безпеки осіб, які беруть участь у кримінальному судочинстві» [19] зазначено, що під забезпеченням безпеки слід розуміти здійснення правоохоронними органами правових, організаційно-технічних та інших заходів, спрямованих на захист життя, житла, здоров'я, майна осіб, які беруть участь у кримінальному судочинстві, тобто у виявленні, попередженні, припиненні, розкритті або розслідуванні злочинів, а також у судовому розгляді кримінальних справ від протиправних посягань.

Важливо зауважити, що використовують саме термін «забезпечення безпеки», а не «захист», останнє вважається наданням правової допомоги захисником, відповідно до норм КПК. Однак, з огляду на зарубіжне законодавство у цій сфері, традиційно склалося, що захист свідків частіше пов'язують саме із забезпеченням їхньої безпеки в рамках відповідних програм захисту свідків - ПЗС. Такі програми, як ми переконались, діють у більшості країн світу, являють собою комплексний інститут, що передбачає систему процесуальних гарантій, засобів та заходів, що у сукупності перешкоджають будь-якому протиправному посяганню на життя та здоров'я, майно зазначених осіб та їхніх близьких [20].

\section{Висновки}

Зважаючи на наведену вище досить велику кількість законів та специфічних програм щодо захисту свідків, а також позитивну практику реалізації права особи на належний рівень судочинства за кордоном і натомість,досить незадовільний стан речей у національному судочинстві, вважаємо, що одним із шляхів вирішенням проблеми $є$ забезпечення захисту свідкам та потерпілим у кримінальному судочинстві. Під захистом слід розуміти забезпечення стану безпеки таким особам в рамках їхнього статусу як учасників кримінального провадження.

\section{Список використаних джерел:}

1. Про схвалення Стратегії розвитку органів системи Міністерства внутрішніх справ на період до 2020 року : Розпорядження КМУ від 15 листопада 2017 р. № 1023-p. URL : https://zakon.rada. gov.ua/laws/show/693-2019-\%D1\%80 (дата звернення: 22.03.2020)

2. Забезпечення безпеки учасників кримінального судочинства: порівняльно-правовий аналіз. URL : http://dspace.onua.edu. ua/bitstream/handle/11300/9754/98473. pdf?sequence=1\&isAllowed=y （дата звернення: 22.03.2020)

3. Гриньків О.О. Забезпечення безпеки учасників кримінального судочинства : становлення і розвиток в окремих зарубіжних країнах. Право $i$ суспільство. 2007. № 4. С. 89-92.

4. Гончаров В. Б., Кожевников В. В. Проблемы безопасности участников уголовного процесса. Государство и право. 2000. № 2. С. 49-51.

5. Защита свидетелей против «коза ностры». URL: http://www.swissinfo.ch/rus (дата звернення: 23.03.2020)

6. Гриньків О. О., Ляш А. О. Заходи забезпечення безпеки у кримінальному судочинстві : монографія. Тернопіль: Астон, 2012. 260 с.

7. Гриньків О. О. Фінансування програм захисту свідків та інших учасників кримінального процесу. Часопис Київького університету права. 2012. № 2. C. 282-285.

8. Брит Г. В. Международный опыт обеспечения безопасности участников уголовного судопроизводства. Вестник Краснодарского университета МВД России. Серия «Государство и право. Юридические науки». 2017. С. 61-64.

9. Брусницын Л. В. Обеспечение безопасности потерпевших и свидетелей. Законность. 1997. № 1. С. 38-39.

10. Краснова К. А. Защита свидетелей в государствах-членах ЕС. Международное право. 2015. № 4. C. $66-86$.

11. Богонюк Г. І. Суб’єктивна сторона складів злочинів, які регламентують кримінальну відповідальність за невиконання судового рішення. Право.иа. 2015. № 2. С. 108-113. 
12. Уголовный кодекс Федеративной Республики Германии от 13.11.1998. URL : http://law. edu.ru/norm/norm.asp?normID=1242733\&subID= 100102942,100102944,100103642,100104127\#text (дата звернення: 24.03.2020).

13. Казакова В. А. Новый закон об обеспечении социальной и правовой защиты свидетелей в ФРГ. Государство и право. 2000. № 9. C. $75-76$.

14. Краснова К. А. Защита свидетелей в государствах-членах ЕС. Международное право. 2015. № 4. C. $66-86$.

15. Епихин А. Ю. Институт безопасности участников уголовного процесса: сравнительный анализ законодательства зарубежных стран. Актуальные проблемы экономики и права. 2008. № 1. С. $139-145$.

16. Підтримання прокурором державного обвинувачення : підручник для студентів вищих юридичних навчальних закладів / $€$. Блажівський, О. Якимчук, I. Козьяков, М. Туркот та ін. Київ : Національна академія прокуратури України, 2014. 512 с.

17. Шапакидзе В. Я. Обеспечение процессуальной безопасности частных лиц в досудебном уголовном производстве : автореф. дис. ... канд. юрид. наук : 12.00 .09 . Волгоград, 2003. 28 с.

18. Гриньків О.О., Ляш А.О. Заходи забезпечення безпеки у кримінальному судочинстві : монографія. URL : irbis.library.te.ua/cgibin/irbis64r 15/ cgiirbis_64.exe? (дата звернення: 24.03.2020).

19. Про забезпечення безпеки осіб, які беруть участь у кримінальному судочинстві: Закон України від 23 грудня 1993 року № 3782-XII. URL : http://zakon3.rada.gov.ua/ laws/show/3782-12 (дата звернення: 24.03.2020).

20. Забезпечення безпеки учасників кримінального судочинства: порівняльно-правовий аналіз. URL : http://dspace.onua.edu. ua/bitstream/handle/11300/9754/98473. pdf? sequence $=1 \&$ isAllowed $=\mathrm{y} \quad$ (дата звернення: 24.03.2020).

The article deals with the problematic aspects of the protection of the witness's safety as a person involved in criminal proceedings. The state of the normative security of the witness is examined using comparative legal analysis of national legislation with the legislation of some foreign countries. The prospects of implementation of some aspects of international law in the legislation of the national legal system have been clarified. It was determined that the legislation of the Republic of Austria, namely Federal Law No. 526, clearly defined the circle of witnesses that could be included in the witness protection program. According to this law, witnesses are persons who are at risk because they have significant information on organized crime, crimes against the government, crimes in the field of drug trafficking and some other serious crimes. Austria's security measures are similar to those of European states: moving a witness to a secure territory, relocating to another place of residence (another city, or even another state); creation of a new "history" of a person's life (legend), registration of new documents; bodyguard; change of identity documents; linking new documents to existing databases; Track email and email based on passwords and logins provided by the client; social adaptation to a new place of residence; psychological assistance to the victim (witness) and the like. It has been found that the French legislation, in order to maximize the protection of witnesses, allows even the complete anonymity of a person's testimony. This is a very effective incentive for the person to give such testimony and enables law enforcement agencies to significantly simplify the procedure for witness protection. It is concluded that the concept of witness and victim protection should include the provision of all three components. However, the concept of security in the law and the theory of criminal proceedings is inconsistent, with no generally accepted definition of "security" in theory.

Key words: comparative law, criminal proceedings, protection of criminal proceedings participants, witness protection program. 